\title{
Text choice for the English (language arts) classroom in New Zealand: Balancing needs and environment in the face of a potential move to increased accountability at Years 9 and 10
}

\author{
Gillian Hubbard \\ School of Education, Victoria University of Wellington
}

The approaches of 17 experienced secondary school teachers of English in New Zealand to choosing text, reported through semi-structured interviews, aligns well to one strand of theory about adolescent literacy. This theory, based on empirical research, advocates taking account of students' interests and backgrounds when choosing texts. New Zealand secondary school English teachers' sense of unencumbered autonomy to choose texts may come under pressure from signalled policy moves for increased accountability for progress in literacy between the primary and secondary school years. The pattern internationally has been for movements to increase accountability to result in a narrowing of curriculum approaches.

Keywords: Literacy, choice, accountability

\section{Introduction}

New Zealand secondary school English teachers are largely free to choose the texts they teach. This leaves them strongly in control of the curriculum content of their classrooms. In recent years, and particularly since the introduction of The Senior Curriculum Guide for English (Ministry of Education, 2012), they have been encouraged to think about their students in terms of such key concepts as identity, communication, story, and meaning. This guide nudges teachers in social constructivist directions, in other words to take stronger account of student background and the positioning of students in society when choosing text. Teachers are currently free to choose texts that speak to student interest and student background, and the research reported here suggests that this is what they tend to do.

The approach advocated through this senior curriculum guide derives from one current strand of research about adolescent literacy, the strand that argues for approaches to adolescent literacy that take account of students' backgrounds and interests. Because New Zealand English teachers are unconstrained by required or recommended lists of texts for curriculum levels, it could even be said that the New Zealand context provides a case study for adolescent literacy development in English through free teacher text choice.

But this is not the only international strand in thinking about adolescent literature. There is another strand of thinking which articulates a sense of crisis about slipping levels of adolescent literacy, often in relationship to measures of literacy both at the national level and through such international testing mechanisms as the OECD ${ }^{1}$ PISA (the Programme for International Student Assessment) which ranks countries' scores against each other.

\footnotetext{
${ }^{1}$ http://www.oecd.org/pisa/aboutpisa/
} 
Currently, these two directions of thinking about adolescent literacy do not sit comfortably together because they come with differing theoretical perspectives and histories which are not easily reconciled. Critics of the movement for increased accountability associate it in particular with policies that narrow the curriculum, lead to teacher performativity, and involve more time on measuring progress rather than time on taking an expansive and flexible approach (Ball, 2003; Darling-Hammond, 2010; Lingard, 2009). New Zealand primary schools have had their traditional approaches to teaching challenged and transformed by the introduction of the National Standards for reading, writing and maths Years 1-8, and at least some have found a narrowing of the curriculum to be one of the results of this change (Smith, Anderson, \& Blanch, 2016; Thrupp, 2013).

Secondary teachers of English in New Zealand seem to have been in some ways insulated from the movement for accountability, and particularly in the junior secondary school at Years 9-10, and so have been able to teach in ways recommended through the English curriculum guides. It cannot, however, be assumed that this position is beyond challenge. One source of challenge could be an increased alignment of expectations for measurable progress in literacy development from the primary into the secondary school level and there are some clear signals that this is an approach under consideration (Ministry of Education, 2017b).

A change of government in the second half of 2017 has in the meantime led to some shifts in policy direction. It has been announced that the National Standards will no longer be used but some form of accountability will be required and it is not clear what this will be. The results of the PIRLS (Progress in International Reading Literacy Study) assessment of primary school level literacy released early in December 2017 (Ministry of Education, 2017a) showed a marked drop in New Zealand rankings for middle school literacy after a relatively stable position in the past. That there will be a resulting soul-searching about the effects of recent policies for primary school literacy makes it a good time to take stock of current practice in English in the secondary school.

An exploratory study of experienced secondary school teachers of English to be reported here, undertaken immediately prior to the implementation of the Senior Curriculum Guide for English, suggested that New Zealand English teachers are open and generous in their approach to text choice. The teachers were sensitive both to their students' literacy needs and the context of their teaching and chose text accordingly. Text choice remains to a certain extent influenced by the requirements of assessment, particularly in the senior school, and this emerges in the study. Despite the awareness of the need to prepare students for assessment, what was not present in this research was the anxiety that accompanies what has become described (following Ball, 2003) as the performativity of teachers constrained by high levels of accountability for progress.

It cannot, however, be assumed that secondary English teachers will remain immune from the accountability movement and if so it seems useful to consider how to best protect existing good practice. The argument of this article will be that the best way to protect flexibility and choice in the teaching of secondary English text may be to strengthen its curriculum or learning design model so that teachers can demonstrate both how they are rigorous in their diagnosis of students' existing literacy needs and how they are also accommodating students' interests and backgrounds when they take account of those needs. The article looks for an articulated middle way to accommodate both flexibility and accountability, so that flexibility to individual and cohort need is not sacrificed to an increased focus on measures of progress. 


\section{The movement for socially situated literacy in English}

Literacy has long been seen as socially mediated (Heath, 1983: Scribner \& Cole, 1981; Street, 1984). The argument for text choice for relevance and to meet interest emerges from social and culturally situated studies of adolescent literacy. Key proponents of this approach, Moje, Overby, Tysvaer, and Morros (2008) reach this point through research with primarily cultural minority students. They see literacy as situated in real life experiences and essential to participation in the societies to which students belong:

[H]aving access to socially constructed and conventionalized codes is central to being part of a community and means having access to certain types of power; it also allows people to adopt the self (or identity) they feel is appropriate or demanded of a particular relationship, space or time. (p. 109)

The need for greater attention to the social context of learning and teaching emerges from some decades of work, including the seminal work of the New London group of multiliteracies (Leander \& Bolt, 2013 and seminal work on culturally responsive teaching (Delpit, 1995; Ladson-Billings, 1994; Moll, Amanti, Neff, \& Gonzalez, 1992; Secada, Fennema, \& Adajian, 1995). The application of their work to the learning area of English can be seen in such work as that of Lee (2006) on cultural modelling which shows that the relevance of content needs to be accompanied by an understanding of the vernacular of student speech when analysing students' ability to interpret the figurative content of texts, both contemporary and canonical. Within the field of English curriculum studies there are continuing strong voices for using digital literacies (Domingo, 2012), Young Adult literature (Knickerbocker \& Bruggeman, 2008), popular culture literature including (in the United States in particular) hip-hop (Petrone, 2013), and culturally relevant texts (Thomas, 2013) including culturally relevant texts in the New Zealand context (Crozier, 2008; Skerrett, 2012; Whatiri, 2006).

That the approach of teaching texts that meet students where they live is now in some sense mainstream and can be seen when they are given in such widely disseminated textbooks for teachers of literacy as Best Practices in Adolescent Literacy Instruction (Hinchman \& Sheridan-Thomas, 2014). This text was contributed to by such currently key literacy specialists in this movement as Moje and Shanahan and Shanahan. The advice tailored to the learning area of English, or language arts as it is sometimes called, is the following:

Teachers who are aware of their students' interests and cultural backgrounds can choose activities, experiences, and texts that students will be interested in and will enjoy. (Rush \& Reynolds, 2014, p. 251)

Where texts are relevant, they argue, student enjoyment and engagement will increase. Motivation through engagement is, in this sense, proposed as the key to increased literacy development. Rush and Reynolds also request increased choice for students:

Teachers who provide students with meaningful, appropriate choice send the message to students that their opinions and preferences matter. (p. 215) 
The Senior Curriculum Guide for English (Ministry of Education, 2012) in New Zealand strongly supports this international movement to relevance and choice in the teaching of English in secondary schools. It asks teachers to "seek input from your students when deciding the focus on an upcoming study" to "discuss with your students which film, novel, or other text to choose for study" to "encourage students, when doing their own reading, to think about the ways in which their reading connects with their own life and experience" and "to choose texts that the students are going to relate to and see as relevant" (p. 32). Potential types of texts include play scripts, news media editorials and reports, game scripts, poems, speeches, letters, essays, reviews, documentaries, CG animations, graphic novels, mime, blogs, mockumentaries, video diaries, electronic journals, lyrics, novels, oral histories, oral narratives, short stories, films and re-used and mashed-up texts. The direction even mandates the need to reverse text choices to meet student response: "If a particular text does not engage them, consider changing it" (p. 32).

While the Senior Curriculum Guide for English describes assessment processes, it is much more strongly focussed on socially situated learning, something it does not seem to feel the need to defend. Internationally, however, proponents of socially situated literacy have started to exhibit the need to advocate for this approach defensively in relation to the movement for increased accountability for progress in literacy. Moje et al. (2008), for example, conclude their study with the following plea to not forget the wider needs of students in the concern for raising literacy level:

[Y]outh read and write for social, emotional, intellectual, and spiritual purposes. Their reading and writing practices foster communication, relationships, and self-expression among peers and family members; support their economic and psychological health; and allow them to construct subjectivities and enact identities that offer them power in their everyday lives. These consequences of literate practice in the everyday world should not be diminished by the quest to improve the school achievement of all young people, even as educators pursue the important goal of closing the achievement gap. (p. 149)

\section{Accountability for literacy, National Standards for Years 1-8 and projected accountability into Years 9-10}

Although both movements have a focus on increased literacy engagement, the movement for increased accountability for literacy development in general and adolescent literacy in particular tends to come from a different place and use a different set of discourses. Currently, much of the concern about levels of adolescent literacy emerges from national and international data sets of literacy such as those produced by PISA. Such data sets tend to become associated with calls for increased accountability for levels of literacy and numeracy, a way of thinking which in New Zealand has resulted in the introduction of the National Standards for reading, writing and maths Years 1-8.

The discourse around accountability has long roots in national policy formation. In a seminal article Barber (2004), one of the architects of the accountability movement in education in the UK through his role as chief advisor to the Secretary of State for school standards from 1997-2001, describes an "effective accountability system" as the guarantee of "a basic minimum of service" (p. 11). Accountability in education is, in Barber's view, allied to models of accountability in the business community and such other public services as 
health and policing. Critics of the accountability movement argue that it results in a "culture of competitive performativity" (Ball, 2003, p. 219) which in turn results in loss of teacher autonomy and efficacy in the face of processes of measurement.

Critics of the introduction of the National Standards for reading, writing and maths Years 1-8 in New Zealand see it as beginning to result in a narrowing of the curriculum and a culture of performativity in New Zealand primary schools (Thrupp, 2013). In May 2017, the then incoming Minister of Education, Nikki Kaye, announced a goal of $80 \%$ of students in the final year of pre-secondary schooling achieving at the National Standard for this final year (Year 8). Currently, 71\% of students are reaching this goal. At the time of revision of this article a change of government and further change of Minister of Education at the end of 2017 has led to the abandoning of National Standards. At the beginning of December 2017 international testing of students at Year 5 under the PIRLS showed that New Zealand students had slipped 11 places in the rankings of countries to $33^{\text {rd }}$ out of 50 countries (Ministry of Education, 2017a). It is hard to say how concern with these results may now manifest in government policy.

There were in May 2017 discrete policy signals that the process of accountability for adolescent literacy and numeracy in line with the National Standards would be extended into the junior secondary school. These were made through the document New Better Public Service Targets for Education (Ministry of Education, 2017b). This document included a very brief mention of the tool for this extension, the Learning Progressions Frameworks designed "to illustrate the significant steps that students take to develop their reading, writing and mathematics expertise from Years 1 to 10 " (p. 2). The tool has exemplification of student work in reading and writing in English, Social Sciences and Science to be used as benchmarks of levels and follows a genre-based approach to this exemplification. This tool is not announced as a compulsory instrument of measurement, but rather the frameworks "are available to all teachers so that they can better understand individual student progress and plan to meet each individual's learning needs" (p. 2).

While nationally norm-measured assessments, including The Literacy Progressions and the E-asTTle assessment tool, already allow for a continuity of assessment of skills between primary and secondary level, they are currently used in a variety of ways by secondary school practitioners and school management. The Learning Progressions Framework, while still not fully articulated as mandated policy, indicates the beginning of a more seamless process of measurement of progress between the primary and secondary school. This could mean that secondary school teachers of English start to face the issues around the implementation of the National Standards that have affected their primary school counterparts. While this remains at the policy indication stage, and the change of government may affect policy in the portfolio of education, there are some signals here that warrant careful attention by secondary school teachers of English in New Zealand.

\section{The concern that pressure for accountability narrows the curriculum}

There has been international as well as New Zealand concern that increased pressure for accountability results in a narrowing of the curriculum and places a sense of pressure and constraint on teachers. Dennis (2013) describes the narrowing of reading instruction approaches for struggling adolescent readers after No Child Left Behind in the United States. Dennis and others (for example, Buly \& Valencia, 2002; Lesaux \& Kieffer, 2010; Rupp \& Lesaux, 
2006) are concerned with a trend to a teaching of constrained reading skills (letter knowledge and phonemic awareness) rather than deep reading skills (vocabulary knowledge and comprehension). Deep reading skills are less amenable to rapid measurable progress, but are ultimately the skills needed to participate in society. What these writers are suggesting is that the need to show rapid measurable progress leads to less open and flexible programmes of teaching for those struggling with adolescent literacy. These findings should be cautionary for New Zealand.

More generally, Darling-Hammond (2007) describes the difference between curricula that develop "rote learning" skills and a "thinking curriculum" (p. 330), also seeing the first as a result of increased testing to standards in the US after the No Child Left Behind Act of 2001. She argues instead for "more skilful and adaptive teaching that enables more successful learning for all students" (p. 330). Closer to New Zealand, Lingard (2010, p. 141) draws a distinction between the "defensive pedagogies" that he argues are the result of the implementation of high-stakes assessment in Australia and "productive pedagogies" that make a difference to what he describes as "high-order education outcomes."

In a study of New Zealand primary school teachers' perceptions of the implementation of the National Standards, teachers reported on the extreme care that was sometimes needed when reporting to parents about students against the standards and on the demoralising effects on students of being told they were "below the standard." The standards seemed arbitrary and the reporting against the standards also diminished opportunities to report on areas outside literacy and numeracy where students were showing strengths. On the positive side however, teachers did find benefits in knowing "where students were 'at"' (Smith et al., 2016, p. 111) and so being better equipped to discuss how to support students' needs with parents.

The signalled development of the implementation of more universally applied tools to measure the literacy progression of students in Years 9-10 in New Zealand comes against this background of a groundswell of concern at the effects of the accountability movement. One of the architects of the accountability movement, Barber (2004) cited above, was unapologetic about the effect of narrowing the curriculum through a return to the basics, seeing this instead as a priority for both primary and secondary school. "I do not think that many primary or secondary schools have yet prioritised English and math sufficiently." His projected solution for the UK was "a change in the indicator at age 16 to require high standards in English and math" (p. 17). In this sense, a possible change in New Zealand for tighter reporting on progress in literacy in the secondary school is part of an agenda predetermined internationally some time ago.

\section{The "crisis" in adolescent literacy internationally}

There is a strong current international concern with adolescent literacy which tends to be expressed through the language of crisis. This can be seen in the United States in the Carnegie Council on Advancing Adolescent Literacy report on adolescent literacy, Time to Act (2010/2011). The thrust of this report is that without literacy skills adolescents will not meet the needs of the global marketplace:

In state after state, the testing data mandated by No Child Left Behind reveals a marked decline in the reading and writing skills of adolescent learners. School systems are now grappling with the fact that promising early performance and gains in reading 
achievement often dissipate as students move through the middle grades. As a result, Many young people drop out of high school or perform at minimal level and end up graduating without the basic skills that they need to do college-level work, get a wellpaying job or act as informed citizens. (p. $x$ )

The report suggests a range of targeted approaches to the problem. One of these is increased monitoring of progress. At one point the report compares an "ideal" school with "normal practice." The section for the ideal school paints a picture of the possible requirements of increased monitoring within a school programme. These include:

Annual diagnostic reading assessments, curriculum guides, common formative assessments, common summative assessments, data ... provided in a timely basis, teachers and entire staff [who] have real-time data on student performance, programs [that] are monitored closely and programs [that] are continually evaluated and reevaluated. (pp. 4-5)

The contrasting currently less ideal "normal practice" scenario is "No school-wide reading assessments, teachers develop their own syllabi, each teacher individualises formative assessments and teachers do not use or share data on student achievement" (Carnegie Council on Advancing Adolescent Literacy, 2010, pp. 4-5).

Here we have the tension between flexibility and accountability articulated. Accountability requires a level of uniformity of delivery and assessment processes. Whatever the intentions, this level of accountability must come to some degree at the expense of the kind of teacher responsiveness and flexibility that is promoted by advocates of English teaching as embedded in, and responsive to students' social backgrounds. The difficult question then is, is there a way to marry some level of accountability for progress without a resulting loss of flexibility and freedom to move to respond to student need? I am not the first to consider this dilemma.

The language of crisis around adolescent literacy is repeated internationally and I will draw here on one example. Sulkunen (2013) applies the language of crisis to the European context and then seeks to provide the language of diversity as the solution:

[M]any European adolescents are struggling with literacy. Hence their choices for secondary studies and future careers are limited and their ability to function in the textbased society is insufficient ... [I]n adolescence, developing adequate literacy skills is urgent. (p. 528)

Sulkunen sees the solution to the problem in the results seen in Nordic countries (citing research from Eurydice, 2011; Garbe, 2009; HLG, 2012; Valijarvi et al., 2007, 2002) where equity of educational access is mandated and supporting low-performers in literacy raises outcomes for all. So too does A Time To Act in its appendix on best practice with literacy skills in which Sulkunen argues for the importance of raising levels not only of comprehension but also critical engagement with text. He makes the argument for increasing student engagement with text through the motivation associated with diversity of text:

Individualised approaches provide a solid framework for learning, not only for struggling readers, but also for other students, including top-performers who need more challenges in developing their literacy further. (p. 537) 
In other words, the article raises the literacy-gap concern and suggests a socially-constructed learning approach solution. Sulkunen acknowledges directly that applying individualised solutions to adolescent literacy makes teaching "a very demanding task" (p. 538). Implicitly though this still means that a flexible curriculum design, one that also accounts for and addresses the progress of the students with both the highest literacy needs and the highest levels of literacy, can be seen, from one international perspective at least, as challenging but possible.

Sulkunen's argument seems particularly relevant to New Zealand. While reading scores have remained relatively unchanged for New Zealand students in the PISA testing rounds, what has continued to raise concern in New Zealand is the spread of scores: "Compared to countries with a similar average score, New Zealand tends to have a larger proportion of both students who can complete only relatively basic reading tasks (below Level 2) and students who are capable of advanced reading tasks (Level 5 and above)" (May, Flockton, \& Kirkham, 2016, p. 16). New Zealand English teachers in particular need to be able to think about their students as individuals as they may often have a range of literacy levels within their English classes.

Some writers have challenged the "crisis" approach to adolescent literacy. As early as 2006 Franzak argued that a narrowing of definitions of literacy tends to follow the "sense of crisis" around literacy with the result of, in effect, defining students into categories of struggling or marginalised readers and writers, sometimes with negative consequences for students in terms of class placement. Because the category "struggling reader" is defined in relation to school measures of literacy, Franzak argues, the placement of students in this category may not relate to the students' wider literacy practices out of school.

\section{New Zealand English teachers choose text in response to need and interest}

Currently, as I have suggested at the beginning of this article, New Zealand curriculum documentation and particularly The Senior English Curriculum Guide (Ministry of Education, 2012) is more strongly orientated to the social context of student reading than to accountability for increases in literacy scores. Because New Zealand English teachers do not have prescribed lists of texts, they are used to choosing texts in relation to need and as the exploratory study to be reported here suggests, did so before the emphasis on choice and relevance was mandated through curriculum guides.

At the end of 2011, with appropriate ethical approval I interviewed 17 experienced English teachers, all either heads of department or faculty or acting in that position. I wanted to find out how experienced English teachers went about the process of choosing the best text to teach to inform my own teaching of pre-service English teachers.

The schools were selected from five geographic regions: upper North Island, Auckland City, lower North Island, upper South Island, and lower South Island. Heads of department in schools were approached one by one until a range of types of schools was achieved. The types of schools included, with some characteristics in common in some schools: schools with a high proportion of Māori students, schools with a high proportion of Pacific students, schools with primarily New Zealand European/Pākehā students, schools with a relatively even distribution of Māori, Pacific and Pākehā students, schools with a large mix of ethnicities and including refugee students (up to 26 ethnicities), rural schools (one remote rural school), schools on 
rural/suburban borders, suburban schools, large schools (rolls of up to 3,000) and small schools (rolls of about 300) and one residential or boarding school. All but one teacher approached agreed to participate.

Data from a semi-structured interview of about an hour, conducted at the schools, were analysed thematically. The questions focussed on texts that had been particularly successful in the year, text choices that had been less successful, how texts were selected, text choice in an ideal world, and advice to beginning teachers on text choice. Three significant themes emerged about the way English teachers choose texts. The first was that the most successful texts were seen as those that captured the most reluctant readers. The second was that the teachers needed to be personally invested in the texts they taught and to like them in order to "sell" them to students. The third was that experience with text had taught teachers that some texts "worked" better to develop understanding of ideas and for assessment purposes than others. These themes are discussed in turn below and the examples are drawn from the entire range of the group.

\section{It got them interested}

The most significant emerging theme was the importance of text choice to capture the interest of struggling readers. This emerged with all the teachers in the study. Texts were successful if they motivated readers who were otherwise disengaged and the teachers discussed these texts in the interviews before other choices that had been successful with already motivated readers. The finding suggests that New Zealand English teachers have a strong commitment to motivating struggling readers and view it as a professional priority. The emphasis on 'relevance' discussed above was in this way embodied in the study.

No teacher in these interviews required a definition of "successful" text choice or text choice that had "worked" with their classes but most interpreted successful in terms of meeting needs. One text described in this way was The Hunger Games (Collins, 2008), which at the time of these interviews was newly popular as a novel and had not at that point been made into a film. One teacher had taught it to a Year 10 class reading much aloud and had found it had captivated a class of largely unmotivated readers:

There has to be a reasonable amount of action. Too much sort of cerebral stuff doesn't necessarily go down well.

Another had paired The Hunger Games with survivor-style reality television shows to highlight themes of media manipulation with a senior class of students who had not achieved strongly in the previous year's NCEA assessments:

It happened to link in with the whole survival thing and the idea, hunting, that actually fitted in with a lot of things some of these boys do.

A successful popular culture text was Andy Mulligan's (2010) novel Trash, which one teacher had taught to a senior class which included non-English speaking immigrant and refugee students because the text was accessible and the themes of poverty in slums spoke directly to the experiences of some students from Asian countries. It opened opportunities for rich discussion at a more appropriate level for these students and three Burmese refugee students "instantly related [the context in the text] to situations in their own country." 
A teacher in a school on a rural/suburban border found Mandy Hager's (2007) novel Smashed about adolescents and driving spoke to the interest of more reluctant senior readers, many of whom were at the stage of getting driving licenses. A teacher in a remote community dependent on coastal tourism and the fishing industry found her reluctant readers were captivated by Witi Ihimaera's (1977) short story, The Seahorse and the Reef based on the loss of traditional shell fish sources due to pollution. It "worked really well ... because the last thing we would want to see here is a major pollution problem." In a more urban school with a lot of students from overseas or rural homes, Graeme Lay's (1998) novella Leaving One Foot Island resonated because "a lot of the students have been in the situation that the main character's in whereby they're sent to live with relatives who can't really afford to have them living with them." In schools with large numbers of Māori and Pacific students the relevance of teaching texts by Māori and Pacific writers was extremely important:

A small group of Māori students ... were completely disengaged from the first unit we did. And when we started reading The Whale Rider they completely switched in and began coming up to me in the playground and saying, "Miss, I stayed up 'till midnight reading last night."

Flexibility in text choice was sometimes based on detailed knowledge of students' backgrounds to the extent that a text that worked one year might not the next with a different set of students. One teacher described teaching Denis Wright's (2010) Violence 101 to a strongly disengaged group in the year of the research, making the following case:

I've got to get these kids interested somehow, and if this is the apparent theme of violence I'll use it and then spin it out in all the other directions I can.

This 'spinning out' included themes of knowing yourself and "how you come to learn about yourself; and being able to admit to your mistakes..." But she said she would not have taught any texts concerned with violence to the students she had taught the previous year: "No they, some of them have seen far too much." It is this level of knowledge of contextual factors that is an affordance of the ability to choose text to meet identified needs and interests.

It is implicit in what has been described to this point that the teachers valued texts that helped develop students' understanding of ideas. Some described this as meeting the dimension of the curriculum which is developing independent personal response. There was some reporting of the success of comparative text work for the development of ideas. One described the helpfulness of a "rich question" for this kind of work, for example "why do you feel it is important to feel that you belong to a place?"

While most of the text choice described so far has been of texts for whole class study, some teachers were also responding to the need to align student interest to texts by allowing choice. Examples of this included choice of plays for senior Shakespeare study, several examples of allowing the class to choose the class film from a pre-selected list and a junior class reading a selection of young adult novels at the end of one year with the purpose of providing recommendations for the teacher choice of a whole class novel for the next year's class.

Teachers were also committed to and deeply engaged in supporting their students' independent reading. One head of department showed the researcher the list of contemporary young adult literature she had taken out from the school library and read her way through so that she was equipped to offer choices to support the diverse tastes of her 
students. She had prepared this list as part of a report to her school board of trustees about the implications for workload for teachers of English.

\section{You have to love what you teach}

The second emerging theme, "you have to love what you teach" concerned text choice based on teacher personal preference. This theme emerged in most of the interviews and often in relation to the question about advice to give beginning teachers about text choice. Teachers saw it as their responsibility to motivate, capture and engage their students with the texts that they had chosen and for this reason described a need to be invested in the text themselves in order to 'sell' it successfully to their students:

I can't sell The Catcher in the Rye. I know the kids love it ... But because I can't engage with it, I can't sell it and they just end up feeling a bit dissatisfied.

This message that "if you are not passionate about it, you're not going to teach it well" was often delivered in an unapologetic and adamant tone as a 'given' that every English teacher understands. Some teachers described their preferences in relation to the text choice of other members of their departments; they couldn't teach choices some of their colleagues made because they didn't work for them:

I guess I go with the books I like, um, because I feel very strongly that my interest in the book will convey to the students. You know I've never taught The Great Gatsby because I don't like it [laughs]. Um, I know other people are passionate about it, and that's great, and it's a good text to teach if you are passionate about it, but I think it has to be something that you really like reading, you know ... Because you have to convince these kids it's worth reading.

Running against the grain of other parts of the study that involved starting with the students' interests first, sometimes the teacher would mention that the text they had chosen because they had liked it might initially have been less interesting to the students. The teachers' own enthusiasm and strategies had won the students over, so by the end of the text study it had also become the students' favourite. Some teachers reported taking account of both their personal preferences and the students' interests and needs:

Basically the teacher choose the texts they're comfortable with, but they bring in too ... what's the ability of the class.

\section{It's got to lend itself to NCEA. And not all texts do...}

Teachers liked teaching texts that engaged students with ideas and this theme is closely linked to the need to teach texts that enabled students to be successful in assessments, although the relationship between these two things was quite complex in the study. Thinking about the kinds of questions that might be asked, particularly in an external response to text examination, operated as a brake on some text choice to meet student interest:

You've got a responsibility for your exam classes, that you're teaching a novel that they can write about in the end of year examinations, there's that component. 
Hubbard, NZ Annual Review of Education (2017) 22: 78-94

This led teachers to avoid taking risks with texts:

When you're talking about Level 3 it's high stakes and you can't afford to faff around and risk too much.

One teacher described teaching war poetry "because you know you're going to get a question on techniques and how they carry the theme or emotion. So it's dead simple to get the kids to write really, really well." Another made a parallel point about teaching Of Mice and Men (2006): "We know the kids 'get' it and that lends itself so well to [the relevant NCEA] questions." Some had formulas for texts that worked for examination purposes. This formula was for Year 11 students, the first year of NCEA examinations:

Do something with a distinctive setting. Do something with a strong central character who goes through a significant change, and if that change can be manifested in some way, you know ... the more change the better, because those lower ability students really need to be writing about concrete aspects of that change.

Ideas that students could relate to easily or easily understand "because they're obvious enough the kids don't have to work too hard to get them" were important with some examination classes because then the students "can focus on expressing their ideas which is what they have trouble with at Year 11." When teaching students preparing for external examinations, then, all the teachers were in some way or another attempting to meet all three aspects of the emerging themes of the study: the students' interests and preferences, their own personal preferences, and the requirements of examinations for examination classes.

\section{Discussion}

The New Zealand English teachers participating in this research showed a high level of commitment to developing the literacy of their students through their approaches to text choice. They did this at the time of this study from a strong sense of professional commitment rather than from a sense of anxiety for delivering measurable outcomes of process in literacy. The mutual enjoyment of the teacher and the students in the text study was a strong feature of their discussion of text choice. New Zealand English teachers' practice in this study seems to be strongly aligned to the international research approaches to socially situated literacy discussed in the opening of this article and the reflection of these research trends in The Senior Curriculum Guide for English (Ministry of Education, 2012).

It may be that the approaches of the teachers in this study are currently less strongly aligned with the movement for increased accountability for literacy development. Although this was not the focus of the study, it is interesting that the language of accountability did not strongly inform their discussion. The teachers were most mindful of the need to match text choice to assessment expectations with their senior classes and it was at this stage that measurement of student progress became part of the equation of text choice but it was still not a dominating feature of their discussion of successful text. Measurable outcomes did not seem to feature in their discussion of text choice for Years 9-10 or in senior classes not assessed through examination. In such senior classes designed for students who had been 
less successful with NCEA examinations, building students' confidence with literacy in the face of previous discouragement became a central focus.

The teachers in this study did not seem to exhibit the signs of teacher performativity described internationally of teachers in systems strongly orientated to demonstrating progress in literacy achievement and being seen in New Zealand in some primary school teachers currently implementing the National Standards. This study then provides a useful benchmark against which to consider any change in teacher approach if there is a shift to stronger national assessment of literacy skills at Year 9-10 in the future. It may be a shift for which they are not currently strongly prepared if this does emerge as the policy to be applied. The potential risk is that if teachers start to become anxious about having to account for progress in literacy, they may respond in ways that reduce rather than expand responsiveness to student background and interest.

The underlying question this article poses is whether it is possible to marry higher levels of accountability for literacy progress and responsiveness to individual needs. I would like to suggest one possible way forward: through more carefully articulated curriculum or learning design.

I have been guided in my own practice as a pre-service educator of English teachers by the language curriculum design model of Macalister and Nation (2010) and have begun to share this model with them when it became apparent to me how much it was influencing my own practice. While this model has been devised for English language teachers in particular, it is an easily transferable model. Sulkunen (2013) has laid down the challenge of the desirable but intrinsically difficult nature of individualised approaches to literacy development. What happens when English teachers start to plan for individualisation is that they become in effect curriculum designers for each of their classes. Where this is the case, principles of design become helpful.

The Language Curriculum Design model (Nation and Macalister, 2010) requires all planning of goals, content and sequencing, format and presentation, and monitoring and assessing to be referred back to principles supported by empirical research. It also requires the planning of the course to take account of both environment and needs analysis. Environment analysis considers the situation of the teaching and learning as well as factors that involve the teacher and the learner. It is enormously helpful to teach this model to preservice teachers of English because it means that the contexts in which they are teaching become recognisable as an intrinsic element of the design process, rather than a situation unique to each teacher that deviates from some kind of hypothetical or ideal teaching scenario which their direct experience does not match.

Curriculum policies are part of the situation of the teaching, as well as more individual school policies. There may be a range of pragmatic constraints in the environment. Lack of student computer access at home or at school is an often mentioned constraint for example. That teachers prefer to teach texts they personally enjoy, as reported in the study above, is an element of the environment analysis. The kinds of preferences of students for particular texts reported above because of students' current life experiences are also a currently natural part of the environment analysis for English teachers. This segment of the design model is the one that most clearly maps against the research of Moje et al. (2008) reported earlier that favours considering student preferences and the context of learning in the selection of texts for literacy work.

The needs analysis element of the model is the one that begins a process of accountability. It requires the course designer to analyse the students' existing skills in 
relation to the course goals to determine what aspects of the skills the students currently lack and so what they need at the beginning of the course. It is at the needs analysis stage that more global measures of literacy such as currently E-asTTle and the proposed Learning Progression Framework can be helpful to understand the literacy skills of both the cohort of students in the class and the more specific needs of individuals, in ways that will then be refined by formative assessment processes within the teaching. The planning needs to be based on good diagnosis if it is to be responsive to need. The model also suggests as much as possible taking account of students' wants: the students' own expectations of the course content and outcomes. To be able to take account of students' wants increases the chances of student motivation and investment in the course. Whether the students' needs are met through overcoming lacks is monitored and determined by the assessment in the course. The overall success of the course is determined by its evaluation. It is, of course, desirable that students' learning needs are met as well as possible by course design and in ways that can be measured in accordance with best principles of assessment.

I have been drawn to this model in my work with pre-service teachers for the very reason that the model articulates a way that accountability for progress needs to and can hold hands with adaptability and flexibility in relation to the environment of the teaching. This formula requires accountability for the diagnosis of student need and progress but leaves the autonomy for the processes of designing the teaching and learning programme with the teacher.

This kind of curriculum or learning design model is a complex mosaic and has lots of moving parts. The study I have reported here suggests that New Zealand English teachers already implicitly work to keep all these parts in some kind of balance and are already supported by current curriculum documentation to do so. It is just how not to sacrifice one part for the other that needs to be more carefully established when there is the potential for one part to start to become valued over the others, the criticism of primary school practice under National Standards.

The tension in the international movements concerned with adolescent literacy tends to come between those who considered it most important to measure progress and those who consider it most important to take the environment into account when looking for good outcomes in adolescent literacy. It is the de facto narrowing that follows the first approach that needs to be most actively resisted so both can have their place. It would be most unfortunate if the pressure of increased teacher performativity is introduced into Years $9-10$ through more uniform attention to literacy progress and this resulted, in the ways suggested by international findings, in a narrowing of the generous curriculum approaches to teaching English described in the study reported here. It would, on the other hand, be desirable if a sound diagnosis of needs led to a stronger marriage between attention to needs and attention to the environment of the teaching and learning as an intrinsic dimension of meeting those needs.

Moje et al. (2008), as we have seen, argue for a generous approach to the nature of adolescent literacy. Sulkunen (2013), speaking from the perspective of the high literacy scores achieved in Finland, also advocates for teachers to have room to move if they are to meet the individualised needs of students:

An ambitious curriculum that is pragmatically orientated towards providing students with the skills and competencies they will need includes a wide concept of text and gives teachers freedom to choose appropriate materials and methods. (p. 537, my emphasis) 
If secondary school English teachers in New Zealand and their international counterparts want to retain and have this kind of ambitious curriculum, this may be a good time to think carefully about the best ways to improve and protect it.

\section{References}

Ball, S. J. (2003). The teacher's soul and the terrors of performativity. Journal of Educational Policy, 18(2), 15-228.

Barber, M. (2004). The virtue of accountability: System redesign, inspection, and incentives in the era of informed professionalism. The Journal of Education, 185(1), 7-38.

Buly, M. R., \& Valencia, S.W. (2002). Below the bar: Profiles of students who fail state reading assessments. Educational Evaluation and Policy Analysis, 24(3), 219-239.

Carnegie Council on Advancing Adolescent Literacy. (2010). Time to act: An agenda for advancing adolescent literacy for college and career success. New York, NY: Carnegie Corporation of New York.

Collins, S. (2008). The hunger games. New York: Scholastic Press.

Crozier, S. (2008). Teaching Pacific Island text to seniors: Sia Figiel's Where we once belonged. English in Aotearoa, 64, 3-16.

Darling-Hammond, I. (2010). The flat world and education: How America's commitment to equity will determine our future. New York: Teachers' College Press.

Delpit, L. D. (1995). Other people's children: Cultural conflict in the classroom. New York: New York Press.

Dennis, D. V. (2013). Heterogeneity or homogeneity: What assessment data reveal about struggling adolescent readers. Journal of Literacy Research, 45(1), 3-21.

Domingo, M. (2012). Linguistic layering: Social language development in the context of multimodal design and digital technologies. Learning, Media and Technologies, 37(2), 177-197.

Franzak, J. K. (2006). Zoom: A review of the literature on marginalised adolescent readers, literacy theory, and policy implications. Review of Educational Research, 76(2), 209248.

Hager, M. (2007). Smashed. Auckland: Random House.

Heath, S. B. (1983). Ways with words: Language, life, and work in communities and classrooms. Cambridge, UK: Cambridge University Press.

Ihimaera, W. (1977). The seahorse and the reef. In W. Ihimaera, The new net goes fishing. London: Heinemann.

Knickerbocker, J. L., \& Bruggeman, M. A. (2008). Making room on the shelf: The place of postmodern young adult novels in the curriculum. American Secondary Education, 37(1), 65-79.

Ladson-Billings, G. (1994). The dreamkeepers: Successful teachers of African American children. San Francisco: Jossey-Bass.

Lay, G. (1998). Leaving one foot island. Wellington: Mallinson Rendell.

Leander, K., \& Boldt, G. (2013). Rereading "a pedagogy of multiliteracies": Bodies, texts and emergence. Journal of Literacy Research Matters, 45, 22-46.

Lee, C. D. (2006). "Every good-bye ain't gone": Analyzing the cultural underpinnings of classroom talk. International Journal of Qualitative Studies in Education (QSE), 19(3), 305-327 
Lesaux, N. K. \& Kieffer, M. J. (2010). Exploring sources of reading comprehension difficulties among language minority learners and their classmates in early adolescence. American Educational Research Journal, 47(3), 596-632.

Lingard, B. (2009). Policy borrowing, policy learning: testing times in Australian schooling. Critical Studies in Education, 51(2), 129-147.

May, S., Flockton, J., \& Kirkham, S. (2016). PISA 2015: New Zealand summary report. Wellington: Ministry of Education.

Ministry of Education. (2012). Senior curriculum guide for English. Retrieved from http://seniorsecondary.tki.org.nz/English downloaded 2.15

Ministry of Education. (2017a). PIRLS 2016: New Zealand's achievement. Retrieved from https://www.educationcounts.govt.nz/_data/assets/pdf_file/0007/183697/PIRLS2016-NZs-Achievement.pdf. Retrieved 11.45.

Ministry of Education. (2017b). New better service targets for education. Retrieved from https://education.govt.nz/news/new-better-public-service-targets-for-education downloaded 2.45

Moje, E. B., Overby, M., Tysvaer, N., \& Morros, K. (2008). The complex world of adolescent literacy: Myths, motivations and mysteries. Harvard Educational Review, 78(1), 107153, 278-280.

Moll, L. C., Amanti, C., Neff, D., \& Gonzalez, N. (1992). Funds of knowledge for teaching: Using a qualitative approach to connect homes and classrooms. Theory into Practice, 31(1), 132-141.

Mulligan, A. (2010). Trash. New York: David Fickling.

Nation I. S. P., \& Macalister, J. (2010). Language curriculum design. New York: Routledge.

Organisation for Economic Co-Operation and Development. (2010). PISA 2009 results: Overcoming social background: Equity in learning opportunities and outcome (Vol. 2). Paris: OECD.

Petrone, R. (2013). Linking contemporary research on youth, literacy and popular culture with literacy teacher education. Journal of Literacy Research, 45, 240-266.

Rupp, A. A., \& Lesaux, N. K. (2006). Meeting expectations? An empirical investigation of a standards-based assessment of reading comprehension. Educational Evaluation and Policy Analysis, 28(4), 315-333.

Rush, L. S., \& Reynolds, T. F. (2014). Literacy support in English/Language Arts classrooms: Motivation, dialogue and strategy instruction. In K. A. Hinchman \& H. K. SheridanThomas (Eds.), Best practices in adolescent literacy instruction. New York: The Guilford Press.

Salinger, J. D. (2010). The catcher in the rye. New York: Penguin.

Scribner, S., \& Cole, M. (1981). The psychology of literacy. Cambridge, MA: Harvard University Press.

Secada, W. G., Fennema, E., \& Adajian, L. (1995). New directions for equity in mathematics education. Cambridge, UK: Cambridge University Press.

Skerrett, A. (2012). Languages and literacies in translocation: Experiences and perspectives of a transnational youth. Journal of Literacy Research, 44, 364-395.

Smith, L. A., Anderson, V., \& Blanch, K. (2016). Five beginning teachers' reflections on enacting New Zealand's national standards. Teacher and Teacher Education, 54, 107-116.

Steinbeck, J. (2006). Of mice and men. New York: Penguin Classics.

Street, B. V. (1984). Literacy in theory and practice. Cambridge, UK: Cambridge University Press. 
Sulkunen, S. (2013). Adolescent literacy in Europe - an urgent class for action. European Journal of Education, 48(4), 528-542.

Thomas, E. E. (2013). Dilemmatic conversations: Some challenges of culturally responsive discourse in a high school English classroom. Linguistics and Education, 24(3), 328-347.

Thrupp, M. (2013). Research, Analysis and Insight into National Standards (RAINS) Project. Second report: Understanding New Zealand's very local national standards. Hamilton, NZ: Wilf Malcom Institute of Educational Research, The University of Waikato.

Whaitiri, R. (2006). Māori literature: The power and the beauty. In M. Mulholland (Ed.), State of the Māori nation: Twenty first century issues in Aotearoa (pp. 81-93). Auckland, NZ: Reed.

Wright, D. (2010). Violence 101. Auckland: Penguin.

Gillian Hubbard teaches English Curriculum Studies in the School of Education at Victoria University of Wellington. Her interest lies in secondary school English (language arts) pedagogy, including text choice for diverse classes and ethical pedagogy in sixteenth century literature.

Email: gillian.hubbard@vuw.ac.nz 